\title{
Assessment of the Energy Conversion on the Thermal Balance and Atmospheric Emissions in Ceramic Tile Product Industry in Tunisia: A Case Study
}

\author{
Imed Ben Salah* ${ }^{(}$, Moufida Ben M'barek Jemaï, Aycer Ben Saad, Safa Mezza \\ Department of Geology, University of Sciences of Bizerte, University of Carthage, Tunis, Tunisia \\ Email: *imed_bensalah@yahoo.fr
}

How to cite this paper: Salah, I.B., Jemai, M.B.M., Saad, A.B. and Mezza, S. (2020) Assessment of the Energy Conversion on the Thermal Balance and Atmospheric Emissions in Ceramic Tile Product Industry in Tunisia: A Case Study. Atmospheric and Climate Sciences, 10, 421-442. https://doi.org/10.4236/acs.2020.104024

Received: April 17, 2019

Accepted: August 14, 2020

Published: August 17, 2020

Copyright $\odot 2020$ by author(s) and Scientific Research Publishing Inc. This work is licensed under the Creative Commons Attribution International License (CC BY 4.0).

http://creativecommons.org/licenses/by/4.0/ Open Access

\begin{abstract}
This work aims to assess the effect of energy conversion (Thermal oil, Natural gas and cogeneration system) on atmospheric emission and energy consumption in ceramic tile product sector in Tunisia. Two tile manufactures were selected. The first plant has two production lines: The first line (FF1) operates with thermal oil with a lower calorific value (LHV) of $9811 \mathrm{cal} / \mathrm{g}$ and the second line (FG1) operating with natural gas has a lower calorific value (HHV) of $10,520 \mathrm{cal} / \mathrm{g}$, ensuring a daily output of 300 tons each one. The second manufacture (SC2) operates with natural gas with the same LHV value. The thermal oil energy balance showed a specific consumption of 0.0481 toe/ton tile product for the FF1 manufacture line, 0.0198 toe/ton of tile product for the FG1 manufacture line and 0.0143 toe/ton of tile product for the SC2 manufactory. The electrical energy consumption was 0.0121 toe/ton of tile product for the FF1 line, 0.0108 toe/ton of tile product for the FG1 line and a production of energy (exergy) of 0.014 toe/ton for the SC2 production line. The specific consumption was split into $40 \%$ for dryer and $60 \%$ for tunnel kilns. The conversion allow to record a dryer reduction rate of $80 \%$ for nitrogen oxides (NOx), 56\% for sulfur oxides (SOx), 56\% for fluorinated compounds, $52 \%$ for chlorinated compounds and $52 \%$ for volatile organic compound. Whereas, the kiln reduction rate was $36 \%$ for nitrogen oxides, $51 \%$ for sulfur oxides, $36 \%$ for chlorinated compounds and $55 \%$ for fluorinated and $50 \%$ for volatile organic compounds (VCOs). Compared to natural gas line, the use of cogeneration system in kiln process shows a decrease of $67 \%$ for NOx emissions, $80 \%$ for SOx emissions, $89 \%$ for fluorinated compounds, $58 \%$ for chlorinated emissions and $64 \%$ for volatiles organic compounds. Compared to thermal oil, the use of cogeneration system reduces the
\end{abstract}


thermal energy consumption by $70 \%$ and allowed to save $30 \%$ of electric energy by generate $20 \%$ of needed electric energy. The specific atmospheric gaseous emission level decrease from $2.066 \mathrm{~g} / \mathrm{kg}$ of tile product for the thermal oil process to reach $0.43 \mathrm{~g} / \mathrm{kg}$ of tile product for cogeneration process.

\section{Keywords}

Ceramic, Energy Conversion, Cogeneration, Energy Balance, Atmospheric Emissions

\section{Introduction}

The development of the construction sector, which has been booming in Tunisia, is one of the main factors influencing the output of the construction ceramics industries. Total installed capacity increased from 7,500,000 tons in 2006 to more than $11,000,000$ tons in 2018 , with an average annual growth rate of $8 \%$. In recent years, this phenomenon has made the construction ceramics sector (tile products) industry is one of the most important in terms of production. The tile production rate is 0.58 ton/citizen in 2018. Tile products are mainly composed of clay; a material that usually contains iron oxide, which gives the ceramic its red hue [1] [2]. Despite the wide variety of products that can be made from tile ceramic, the production process is basically the same, which does not depend globally on the materials used or the final product. This process consists of the following stages: extraction, storage and preparation of raw materials, shaping, drying, and firing [3]. The properties of the expected tile products are their high strength, long life and lack of toxicity [4] [5]. However, while economically prosperous, this activity is often still rudimentary and has environmental impacts throughout its production stages [6]. In addition, the manufacture of tile products was considered as energy consumer industry because the use of very high temperatures to convert raw material (clay and mixtures) into a paste with very different properties [7]. Energy accounts for $45 \%$ to $55 \%$ of total production costs. Based on two representative production manufactories, this study pinpoints the effects of energy conversion from thermal oil to natural gas, presents the arguments for the use of cogeneration technology, and aims to promote energy optimization and valorization in Tunisian tile manufactories in order to balance industrial and environmental parameters.

\section{Materials and Methods}

\subsection{Study Manufacture Description}

Two tile product manufactures are studied: the first is located $180 \mathrm{~km}$ from $\mathrm{Tu}$ nis city in the south direction. It is composed of several production lines that use two different types of fuel (thermal oil (FF1) and natural gas (FG1)) and the second plant (SC2) is located at $60 \mathrm{~km}$ from Tunis city (Figure 1). All production lines have the same manufacturing process. The thermal capacities of dryer 


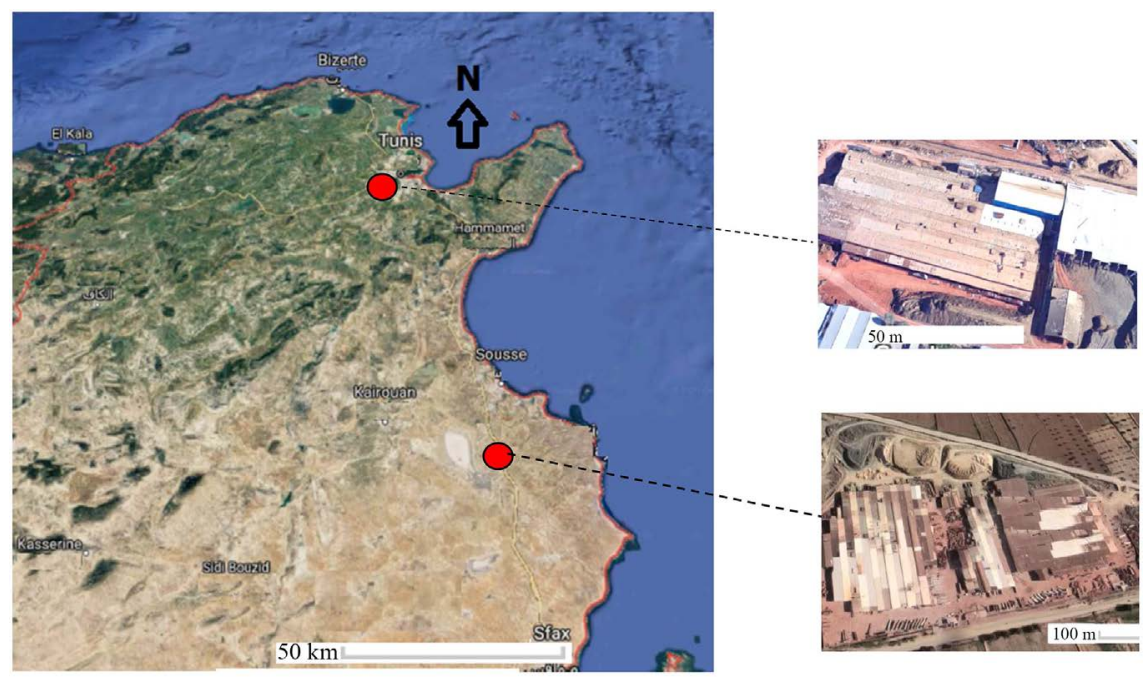

Figure 1. Ceramic product factory's location (Google Map).

and tunnel kiln are respectively 4000 th/h and 7000 th/h. The cutting equipment of tile product, loading and unloading slats will allow to achieve a production of 6000 pieces/hour. This implies a daily production of 300 tons/day and an annual production between 85,000 tons to 100,000 tons by each production line. The Analysis of the data collected highlighted that the two tile manufactures are not provided with equipment for the treatment and reduction of atmospheric pollution. The thermal oil is stored in underground tanks in the open air as a result; it will have to be heated before being pumped while natural gas is supplied directly through the pumping station.

\subsection{Tile Process Description}

The process of ceramic tile starts by selecting the raw materials and, after a first mixing of the basic components, milling them in continuous mills with a mixture of water. A first water removal is carried out by spray drying [8]. Then, forming takes place by mechanically compressing the paste in the die. After that, the tile body is dried again to appropriate levels for firing (pre-heating, heating, cooling). The temperature in the kilns is about $950^{\circ} \mathrm{C}$ [9]. Firing is mainly carried out in tunnel kilns. Burners provide the required firing heat. The movement of the tiles is against the current with respect to the internal flow of the kiln [10]. The fireplace at the entrance to the oven provides a negative temperature gradient, which maintains a pressure lower than that inside the chambers, which causes a movement of cold air for rapid cooling [11]. Return air to the kiln inlet area is used to transfer thermal energy from the firing zone to the incoming material, thus performing a preheating phase without installing burners in preheating zone [12]. Firing and preheating gases are exhausted at a temperature about $250^{\circ} \mathrm{C}$ and the cold air introduced in the cooling zone exits by chimneys located in the system end area [13]. The energy sources used in the ceramic process are fuel-oil, natural gas and electricity. The heating process is responsible for $70 \%$ of thermal consumption. The residual heat sources of the different 
types of dryers (dryer) are low temperature and with a relatively high water vapor content. The addition of fresh air contributes to the cooling of the oven at a final temperature of $70^{\circ} \mathrm{C}$ [14]. The flow of exhaust gases from the kiln, despite being loaded with pollutants and dust, has the highest energy and interesting temperature levels $\left(220^{\circ} \mathrm{C}-250^{\circ} \mathrm{C}\right)$, and flow rate $\left(10,000-15,000 \mathrm{Nm}^{3 /} \mathrm{h}\right)$ which potentially corresponds to the recovery of $400 \mathrm{KW}$ of thermal power.

\subsection{Cogeneration System Description}

The principle of cogeneration consists of producing both electrical and heat energy in the same installation from the same source. For the tile manufactories, the material is dried before entering the kiln using fuel burners (Fuel oil or natural gas) necessary to heat the air [15]. This results in the emission into the air of combustion gases, particles, etc., in more or less quantity depending on the fuel used. The installation of a system allowing the recovery of the hot gases produced by the oven can lead to the reduction, or even elimination, of the fuel consumption for drying. Cogeneration system (Figure 2) consists of a turbo-generator group (air compressor and turbine), with a nominal power of 3 Mwe, sufficient to supply hot gas to the dryer [16]. Electrical energy produced will be exported to other industrial installations or will be exported to the power plant. Exhaust gases must also be diluted with fresh air to maintain the drying temperature specified. Excess heat can be reused for preheating the combustion air (using an energy exchanger). The average temperature of the recovered heat varies between $150^{\circ} \mathrm{C}$ and $250^{\circ} \mathrm{C}$. Heat recovery by the dryer reduces the consumption of total thermal energy [17]. The temperature of the air introduced into the dryer from the mixing chamber varies between $100^{\circ} \mathrm{C}$ and $150^{\circ} \mathrm{C}$ for tunnel ovens. This is evacuated in the form of an air flow and reintroduced into the pre-oven or into the mixing chamber where it will be combined with the recovered combustion air and reused as combustion air through the oven nozzles. The implementation of this system offers a reduction in overall company emissions, the percentage of which depends on the type of fuel used in the dryer [18].

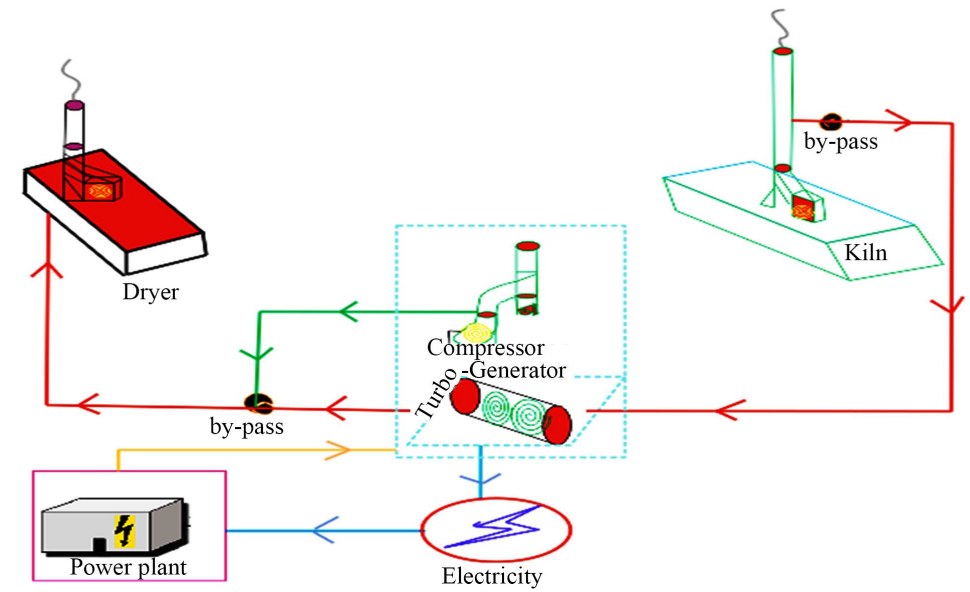

Figure 2. Cogeneration system diagram. 


\subsection{Diagnosis of Thermal Energy}

The experimental measurements in the two industrial selected manufactories is performed in a steady-state mode. There were no changes in the pressure and temperature variables of the drying and firing cycle. The quantity of fuel used in the drying and firing stage was measured with the ramp-type industrial scale, before being dosed in the combustion chambers of the dryer and tunnel kiln [19]. The calculation of the thermal energy generated to supply the tile product manufacturing process was determined with the estimation of the mass of the fuel related [20] with the calorific value (1). The value of the thermal energy generated in the drying and firing stage was calculated using the expression:

$$
E t=m c \times c p
$$

The heat balance is carried out based on the various transfers and exchanges at the tunnel kiln, namely the exchanges linked to the load, the kiln walls and the gas. The thermodynamic balance allows the correlation between the three parameters [21]:

1) Mean temperature of the load at time $(t)\left(T_{s}(z, t)\right)$ according to formula (2)

$$
\begin{aligned}
T_{s}(z, t) & =\rho_{s} C_{p s} S_{h}(1-\varepsilon) \delta T_{s}(z, t) \\
& =A_{G s}\left[T_{g}(z, t)-T_{s}(z, t)\right]+B_{p s}\left(T_{P}^{4}-T_{s}^{4}\right)
\end{aligned}
$$

2) Gas temperature at time $(t)\left(T_{z}(z, t)\right)$ according to formula (3)

$$
\frac{S_{h} \varepsilon \delta\left(\rho_{g} \cdot C_{p g} \cdot T_{g}\right)}{\delta t}+\frac{\left(D_{m g} \delta\left(C_{p g} \cdot T_{g}\right)\right.}{\delta z}=A_{g s}\left(T_{s}-T_{g}\right)+A_{G T a}\left(T_{a}-T_{g}\right)
$$

3) Mean temperature of the inner surface of the wall at point $(z)$ at time $(t) T_{p}$ $(z, t)$.

\subsection{Fuel and Natural Gas Process Analysis}

For the fuel oil, analysis of elements of mineral origin is fulfilled by using physical methods such as X-ray fluorescence and plasma emission spectrometry [22]. The crystallization state is accomplished by X-ray diffraction. Weight methods such as infrared spectrometry and thermogravimetry are used to perform carbonaceous materials [23]. The percentage of water (water contents between 50 and $1000 \mathrm{mg} / \mathrm{kg}$ of sample) is fulfilled by the Karl-Fisher method in the presence of pyridine [24] which neutralizes the acids formed and anhydrous methanol as solvent for iodine and sulfur dioxide. The final titration point is established by amperometry [25]. Natural gas can contain $\mathrm{C}_{3}$ and $\mathrm{C}_{4}$ hydrocarbons, which form the LPG fraction. The heaviest fraction corresponds to hydrocarbons with five or more carbon atoms $\left(\mathrm{C}_{5+}\right.$ fraction). Natural gas can also contain water and acid gases (carbon dioxide and hydrogen sulfide as well as nitrogen and helium or argon or metallic impurities (mercury and arsenic). The procedure used to analyze the composition consists of taking a checked and stabilized condensate sample from a separator. The various fractions collected are analyzed by gas chromatography on a column filled for the gas fractions and on capillary column 
for liquid fractions. The mixture obtained is injected into a carrier gas (helium) which circulates in a column filled with a stationary phase on which the constituents present in the mixture are adsorbed. All of the hydrocarbons lighter than $\mathrm{C}_{11}$ are fulfilled by the capillary columns, which are small diameter $(0.25$ to 1 $\mathrm{mm})$. After splitting by liquid phase chromatography, the fraction heavier than that $\mathrm{C}_{11}$ is established by gel permeation chromatography [26].

\subsection{Atmospheric Pollutant Measurement}

Measurement of pollutants in the ambient air is numerous and vary according to the type of compound sought. The volumetric and concentration flows (corresponding to $18 \%$ by volume of oxygen) are determined at the Standard state (273 ${ }^{\circ} \mathrm{K}$ temperature and $1013 \mathrm{hPa}$ pressure) under a stationary operating regime while maintaining stable pressure variables. Nitrogen oxides (NOx) analysis is carried by chemiluminiscence [27] which consists of an emission of light energy resulting from a chemical reaction. It is used for measurement of nitric oxide (NO) because it reacts with ozone. Nitrogen dioxide is measured by reduction to nitric oxide. Carbon monoxide (CO) is measured by IR absorption [28] using a $C O 11 M$ type device: A beam emitted by the infrared source passes alternately through a cell filled with $\mathrm{CO}$, a neutral cell and then the measurement chamber before passing through an interference filter placed before the detector. A $S F$ $2000 G$ type device makes the measurement of sulfur dioxide $\left(\mathrm{SO}_{2}\right)$ by $U V$ fluorescence [29]. The sulfur dioxide $\left(\mathrm{SO}_{2}\right)$ molecules are excited under the action of intense UV radiation (214 nanometers). Sulfur dioxide $\left(\mathrm{SO}_{2}\right)$ then de-excites very rapidly by emitting UV radiation of longer wavelength (between 320 and 380 nanometers) than that of the excitation radiation. A photomultiplier makes it possible to calculate the concentration of $\mathrm{SO}_{2}$. Volatile organic compounds (VOCs) are determined with $A G C 2000$ (gas chromatography) by pumping air through an adsorbent material that retains Volatile Organic Compounds that will be separated on the analytical column to be quantified.

\section{Results and Discussion}

\subsection{Description of the Manufacturing Process}

\subsubsection{Raw Materials}

The tile products manufactories use a wide variety of materials to adapt to the diversity of its product line [30]. They use natural materials such as ordinary clay minerals (Table 1), which are hydrated aluminum silicates [31]. The diversity of the composition of the raw materials causes a great variation of product propriety [32], energy consumption and gaseous emissions [33]. In this study case, the natural raw materials used are mainly clays. The chemical composition (Table 1) is dominated by silica, alumina and iron oxide, which gives red color for tile.

The same result is reported by [1] [9] [14] where Tunisian ceramic clays were mainly composed of silica (33\%), alumina (15\%), iron oxide $(6 \%)$ and minor 
Table 1. Chemical composition of clay for tile.

\begin{tabular}{cc}
\hline Chemical oxides & Average (\%wt) \\
\hline $\mathrm{SiO}_{2}$ & 61.05 \\
$\mathrm{Al}_{2} \mathrm{O}_{3}$ & 13.04 \\
$\mathrm{Fe}_{2} \mathrm{O}_{3}$ & 5.25 \\
$\mathrm{MgO}$ & 2.2 \\
$\mathrm{CaO}$ & 7.25 \\
$\mathrm{Na}_{2} \mathrm{O}$ & 1.58 \\
$\mathrm{~K}_{2} \mathrm{O}$ & 2.58 \\
$\mathrm{TiO}_{2}$ & 1.64 \\
$\mathrm{SO}_{3}$ & 2 \\
Los of $\mathrm{Ignition}$ & 9.8 \\
\hline
\end{tabular}

amount of potassium oxide (3\%). Mineralogical analysis by X-ray diffraction (XRD) quartz, calcite, kaolinite (65\% - 70\%) and illite (15\%) associated with low percentage of interstratified illite-smectite (5\%). Other authors reported similar composition for Brazilian ceramic tile where, the main minerals found in these clay rocks are illite and small amounts of smectic clay and kaolinite, as well as quartz, feldspar, hematite and iron hydroxides. The main oxides present and their approximate compositions are: $\mathrm{SiO}_{2}(67 \%), \mathrm{Al}_{2} \mathrm{O}_{3}(15 \%), \mathrm{Fe}_{2} \mathrm{O}_{3}(5 \%), \mathrm{K}_{2} \mathrm{O}$ (3\% - 4\%), $\mathrm{Na}_{2} \mathrm{O}(0.5 \%)$ and $\mathrm{CaO}(0.5 \%)[34]$.

\subsubsection{Description of the Studied Production Lines}

The overall process of red products was relatively uniform [35]: The raw materials are mixed and extruded to take shape. Water is regularly used for mixing and shaping. Dosage is carried out by feeders. In many cases, mixing water is added to the mixture at the end of the feeder until the water content is about $20 \%$. Progressive crushing of materials is adopted to obtain a maximum particle size of less than $1.8 \mathrm{~mm}$. When the desired plasticity is reached, the mixture is homogenized, followed by a molding process which includes extrusion, slip casting, pressing, tape casting and injection molding [36]. After the pieces are molded, raw ceramics contains $18 \%-25 \%$ of residual water, which must be decreased by a multi-stoe rapid drying process ( 2 hours to 4 hours) at a temperature of about $120^{\circ} \mathrm{C}$ to $150^{\circ} \mathrm{C}$. The pieces are ready for burning when a residual water content of approximately $6 \%$ is achieved. The dryers are heated mainly by the residual heat of the kiln (hot air recovered from the cooling zone of the kiln), reinforced by natural gas or thermal oil burners [36]. The residual water will be dissipated by evaporation or by entrainment of the product, which is placed in the kiln by wagons [37]. The red products are fired in tunnels with a length of $130 \mathrm{~m}$ in an oxidizing atmosphere equipped with 12 burner plants. The dry red products are placed directly on the tunnel kiln and are fired at a temperature of between $800^{\circ} \mathrm{C}$ and $950^{\circ} \mathrm{C}$, where the final characteristics, such as color and re- 
sistance, are obtained [38]. After five hours, the red products are cooled to $50^{\circ} \mathrm{C}$. During firing process, a temperature gradient is necessary to fire properly the red products. It will then require controlled cooling so that the products release their heat gradually while preserving their structure [39].

\subsubsection{Energy Consumption}

\section{1) Thermal energy}

In the tile product industry, the main energy consumption is concentrated at the dryer and the kiln [40]. The thermal energy used comes from the thermal oil for the FF1 production line and natural gas for the FG1 and SC2 production lines. Electrical energy is used only in rotating machinery and lighting. The thermal oil used has low sulfur amount (3 wt\%). It has a lower calorific value (LHV) of $9811 \mathrm{cal} / \mathrm{g}$ and a higher calorific value $(\mathrm{HHV})$ of $10,431 \mathrm{cal} / \mathrm{g}$. Its kinematic Viscosity is variable: It is at $50^{\circ} \mathrm{C}$ of $406.3 \mathrm{~mm}^{2} / \mathrm{s}$ and $38.4 \mathrm{~mm}^{2} / \mathrm{s}$ at $100^{\circ} \mathrm{C}$. Its flash point is $101^{\circ} \mathrm{C}$. The chemical composition of the fuel oil is reported in Table 2.

The thermal energy of unit FG1 and SC2 is produced by natural gas at medium pressure. The service pressure is relieved by a transformer station (20/2 bars). The hourly flow is on average 10,000 Th/h. Natural gas has an LHV of $10,520 \mathrm{cal} / \mathrm{g}$ and an $\mathrm{HHV}$ of $11,520 \mathrm{cal} / \mathrm{g}$. The chemical composition of natural gas is reported in Table 3.

The thermal balance [41] in fuel has been calculated by taking into account the various heat transfers inside and outside the furnaces namely: load, gas and walls [42]. The thermodynamic balance makes it possible to establish the heat transfer equations between the different variables [43]. The FF1 line liquid thermal oil dryer has a specific fuel consumption of 0.0481 toe/ton of red product produced that is equivalent to an average of $49.13 \mathrm{~kg}$ of thermal oil/ton of tile product. The dryer consumes 0.0198 toe/ton of tile produced, that is equivalent to $20.14 \mathrm{~kg}$ of thermal oil/ton of tile product. Dryers of the FG1 and SC2 are similar and they running on natural gas. The specific consumption is 0.064 toe/ton of tile product for the FG1 whereas the specific consumption is 0.051 toe/ton of tile product for the SC2 line. The heat loss (Figure 3 ) is concentrated mainly in the heat of evaporation with a percentage of $72 \%$ followed by $14 \%$ of chimney heat loss and $5 \%$ of product or surface heat losses. The uncontrolled loss is about $2 \%$.

Table 2. Chemical composition of thermal oil.

\begin{tabular}{cc}
\hline Chemical element & value \\
\hline $\mathrm{H}_{2} \mathrm{O}$ content & $<0.1 \%$ \\
$\mathrm{Cl}_{2}$ content & $12 \mathrm{mg} / \mathrm{kg}$ \\
$\mathrm{F}$ content & $<1 \mathrm{mg} / \mathrm{kg}$ \\
$\mathrm{N}_{2}$ content & $0.31 \%$ \\
$\mathrm{C}$ content & $87.8 \%$ \\
H content & $11.48 \%$
\end{tabular}


Table 3. Elemental analysis of natural gas.

\begin{tabular}{ccccccccccc}
\hline Element & $\mathrm{C} 1$ & $\mathrm{C} 2$ & $\mathrm{C} 3$ & $\mathrm{IC} 4$ & $\mathrm{NC} 4$ & $\mathrm{IC5}$ & $\mathrm{NC5}$ & $\mathrm{C}^{6+}$ & $\mathrm{N}_{2}$ & $\mathrm{CO}_{2}$ \\
\hline Content $(\%)$ & 76.16 & 11.36 & 6.6 & 0.71 & 1.56 & 0.3 & 0.3 & 0.15 & 2.6 & 0.57 \\
\hline
\end{tabular}

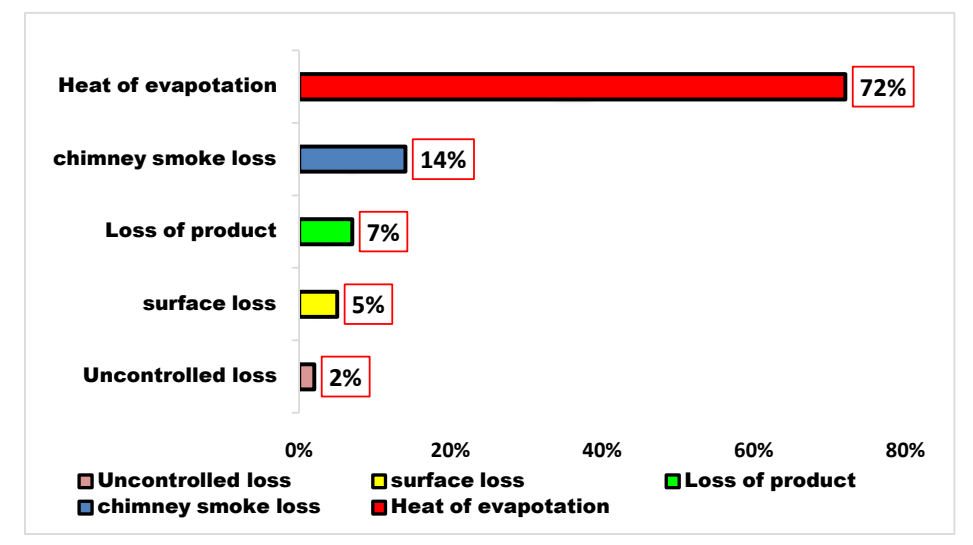

Figure 3. Dryer's heat loss distribution.

The firing kiln of FF1 line consumes 0.0284 toe/ton of tile product, which is equivalent to $28.987 \mathrm{~kg}$ of thermal oil/ton of tile product, unlike the tunnel kiln of the FG1 and SC2 line are almost similar and consumed 0.0948 toe/ton of tile product. Heat loss (Figure 4) occurs mainly in the heat of reaction (35\%), the heat carried away by the circulation of pre-furnace and the furnace (30\%), the surface heat carried away by the product (15\%) followed by loss heat generated by the kiln wagons (5\%) and the recovery heat (5\%). The uncontrolled losses are $5 \%$. [44] specified that the average energy consumption in this process of ceramic tiles is estimated at $705 \mathrm{kWh} / \mathrm{t}$ fired product, of which between $5 \%$ and $20 \%$ is used in firing the product, while the rest is lost via the kiln stacks, through the kiln walls and cracks, and with the tiles that exit the kiln. It may be observed that about $50 \%$ of the energy input into the firing process is lost through the kiln combustion flue gas and cooling gas stacks. The thermal energy consumption is divided between $60 \%$ and $40 \%$ for the dryer. This distribution is different from that found by [45]. They indicate that the consumption of thermal energy in the production process of ceramic tile in the metropolitan area of Cúcuta is distributed in the firing stage with $65 \%$ and in drying with $35 \%$. The thermal efficiency of a tunnel kiln is higher than $70 \%-75 \%$, referred to the heat of combustion and the calorific value of the fuel, being more energy efficient than a Hoffmann kiln, which ranges between $50 \%$ and $55 \%$. The same behavior occurs with the chamber dryer that is $45 \%$ - $55 \%$ efficient, while that of a tunnel dryer is greater than $70 \%$. [46] points out that the thermal energy consumption for the manufacture of ceramic tile in Spain and Brazil reaches 30\% in drying process and $70 \%$ in firing process. This is due to the integration of automation.

\section{2) Electrical energy}

The electrical energy used in the two production manufactories represents $20 \%$ of the total energy required. This electrical energy requirement corresponds 


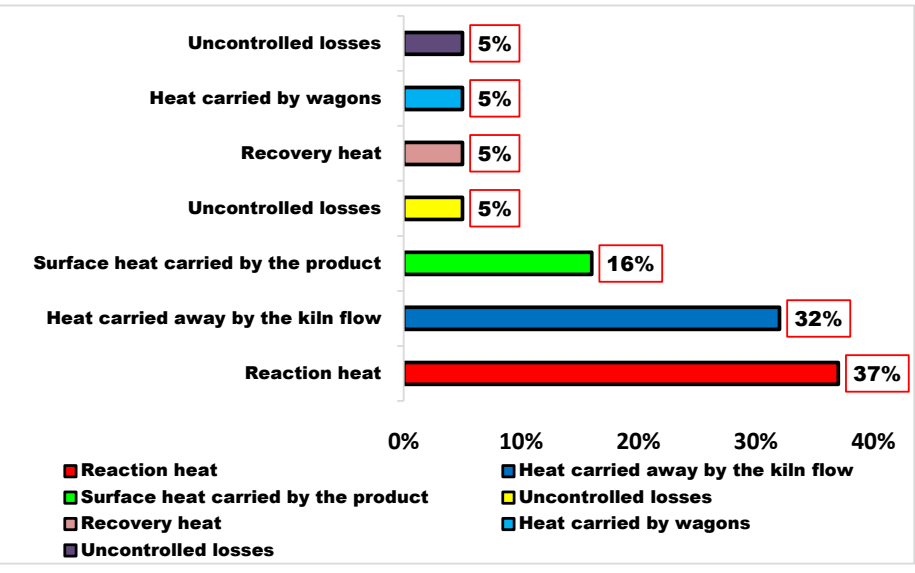

Figure 4. Firing's heat loss distribution.

to a specific electricity consumption of 0.0121 toe/ton of tile produced, which is equivalent at $43.13 \mathrm{kWh} /$ ton of tile product. The analysis of electrical energy consumption highlights that the tunnel kiln and the dryer consumes equitably the majority of the electrical energy requirement (15\% - 17\%), whereas $6 \%$ of this energy is intended for the thermal oil line. A detailed analysis of the electrical energy consumption has been carried out in different tile product manufacturing processes and highlights the following elements (Table 4).

For both lines FF1 et FG1, Table 4 shows that the electric energy is respectively distributed with $12 \%$ to $15 \%$ for raw material process, $20 \%$ to $30 \%$ for the tile product manufacturing process, $12 \%$ to $23 \%$ for dryer, $11 \%$ to $20 \%$ for the kiln and $6 \%$ to $8 \%$ for the compressors. For the production line SC2, the totality of electrical energy is distributed to $10 \%$ for the raw materials process, $12 \%$ for the tile product manufacturing process, $18 \%$ for kiln. Moreover, the dryer and kiln electrical energy needs decreased to reach respectively $8 \%$ and $18 \%$. The compressor electrical energy increases to reach $8 \%$. This result is consistent with the measurement of electrical energy made to the equipment that make up the ceramic industrial facilities in the metropolitan area of Cúcuta, the estimated energy demand required for the manufacture of ceramic bricks is: 42,000 $\mathrm{kWh} /$ month [29]. The four stages of the process of manufacturing ceramic bricks in the metropolitan area of Cúcuta with the highest electric power consumption are: extrusion with $32 \%$ of the electrical energy consumed in the production plant, preceded by firing with $28 \%$, drying with the $19 \%$ and $11 \%$ grinding of electricity consumption in industrial facilities. This is because the extrusion operation demands a high power of the forming system; which includes the model and cut of the wet material, where a product with adequate plasticity and compaction must be guaranteed to meet the technical parameters of mechanical [45]. While in the firing cycle, the electricity consumption is determined by the ventilation system and recirculation of the air flow [47]; together with the energy provided for the milling and dosing of the coal to the combustion burners of the tunnel kiln. In the FF1 product line, electrical energy is used 
Table 4. Electricity consumption distribution in tile production process.

\begin{tabular}{cccc}
\hline & Line FF1 & Line FG1 & Line SC2 \\
\hline $\begin{array}{c}\text { Raw Material process } \\
\text { Tile product } \\
\text { manufacturing process }\end{array}$ & $15 \%$ & $12 \%$ & $10 \%$ \\
Dryer & $30 \%$ & $22 \%$ & $12 \%$ \\
Kiln & $23 \%$ & $12 \%$ & $8 \%$ \\
Turbo generator \\
(Compressor + motor) \\
Thermal oil line
\end{tabular}

at a rate of $20 \%$ compared to the line FG1 in which this rate decrease to reach $16 \%$. Moreover, the SC2 line the electrical energy needs reach $12 \%$ due to the energy supplied by cogeneration process (Figure 5 ). The excess of electric energy in FF1 line is probably justified by the heating of the thermal oil line and the amount of energy lost. [45] highlighted that the overall energy efficiency (electrical and thermal) in the Spanish and Brazilian ceramics industry compared to that of Cúcuta (Colombia) is higher due to the type of technology and automation of the production plants, the measurement and control of energy losses, and cogeneration systems with high yields. The production of the ceramic piece consumed $85 \%$ of natural gas and $15 \%$ of electricity. However, other studies reported lower contributions of natural gas: in Italy, a flooring ceramic tile factory consumed $69 \%$ of natural gas and $31 \%$ of electricity [35]. In Spain, the energy consumed during the manufacturing process of ceramic tiles was $78 \%$ natural gas and $22 \%$ electricity [34]. In Portugal, a tile factory reported that natural gas consumption represented $98 \%$ of the total energy consumption [35]. Koroneos and Dompros [36] calculated the energy consumption in a Greek tile manufacturing process, with pet-coke being the main energy source with almost $100 \%$ of the total energy consumption. The manufacturing process of a Thai ceramic tile consumes $62 \%$ of liquefied petroleum gas (propane and butane), $24 \%$ of electricity and $14 \%$ of kiln oil [37].

\subsubsection{Gaseous Emissions Generated by Tile Product Manufacture}

Gaseous compounds released during drying and firing are derived from combustible that contribute to gaseous pollutants. The main pollutants are respectively: sulfur dioxide, nitrogen dioxide, mono-carbon monoxide, VOCs, fluorides and chlorides. Sulfur dioxide $\left(\mathrm{SO}_{2}\right)$ is a dense, colorless and toxic gas; inhalation is strongly irritating. Nitrogen oxides (NOx) are mainly produced by thermal "fixation" of nitrogen and oxygen. Carbon monoxide, $\mathrm{CO}$, results from the combination of organic material in the ceramic paste, particularly under low oxygen conditions. It can also be formed by the reaction of "fixed carbon" in the pulp with the carbon dioxide $\left(\mathrm{CO}_{2}\right)$ released by the thermal dissociation of the 
alkali and alkaline earth carbonates. Volatile organic compounds (VOCs) occur at the beginning of the heating process by the carbonization of organic compounds. Chloride compounds are present in atmospheric emissions following the decomposition of inorganic salts containing chloride at temperatures above $850^{\circ} \mathrm{C}$ and organic compounds containing chloride at temperatures between $450^{\circ} \mathrm{C}$ and $550^{\circ} \mathrm{C}$. The fluoride compounds arise from the direct decomposition of the fluoro-silicates present in the clay material at a temperature of $550^{\circ} \mathrm{C}$ to $750^{\circ} \mathrm{C}$ or by the decomposition of $\mathrm{CaF} 2$ at temperatures exceeding $900^{\circ} \mathrm{C}$ [48]. The firing process essentially generates the gaseous emissions. The data shown in Table 5 show the emission values produced in different tile product manufacturing line (FF1, FG1 and SC2).

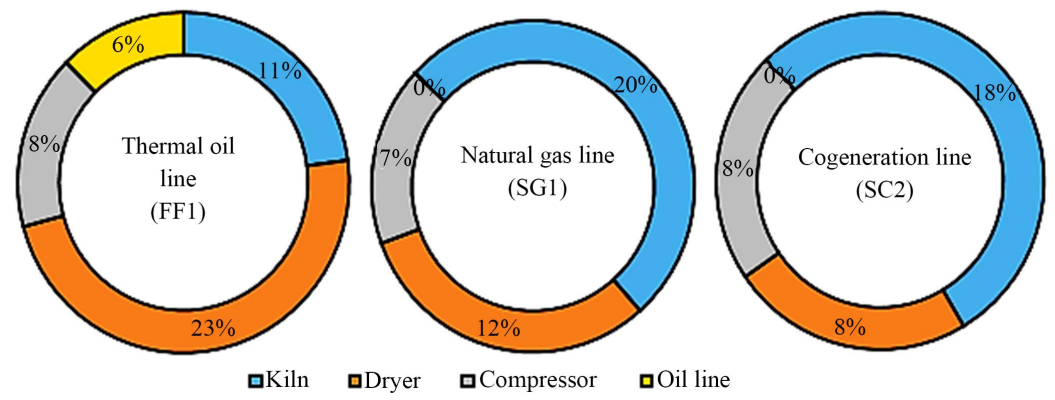

Figure 5. Electricity consumption distribution.

Table 5. Air pollutant values different product process.

\begin{tabular}{|c|c|c|c|c|c|c|c|}
\hline \multicolumn{2}{|c|}{ Atmospheric emissions } & \multicolumn{2}{|c|}{$\begin{array}{c}\text { Product } \\
\text { line FF1 } \\
\text { (Thermal oil) }\end{array}$} & \multicolumn{2}{|c|}{$\begin{array}{c}\text { Product } \\
\text { line FG1 } \\
\text { (Natural gas) }\end{array}$} & \multicolumn{2}{|c|}{$\begin{array}{c}\text { Product } \\
\text { line SC2 } \\
\text { (Cogeneration) }\end{array}$} \\
\hline & & $\begin{array}{l}\text { Drying } \\
\text { Process }\end{array}$ & $\begin{array}{l}\text { Firing } \\
\text { Process }\end{array}$ & $\begin{array}{l}\text { Drying } \\
\text { Process }\end{array}$ & $\begin{array}{l}\text { Firing } \\
\text { Process }\end{array}$ & $\begin{array}{l}\text { Drying } \\
\text { Process }\end{array}$ & $\begin{array}{l}\text { Firing } \\
\text { Process }\end{array}$ \\
\hline Nitric oxide (NO) & $\mathrm{mg} / \mathrm{m}^{3}$ & 6.35 & 9.13 & 3.95 & 32.97 & 2.2 & 21.8 \\
\hline $\begin{array}{l}\text { Nitrogen oxide } \\
\quad(\mathrm{NOx})\end{array}$ & $\mathrm{mg} / \mathrm{m}^{3}$ & 11.25 & 123.25 & 6.25 & 58.53 & 2.5 & 27.5 \\
\hline $\begin{array}{c}\text { Total Nitrogen } \\
\text { Oxide or equivalent }\end{array}$ & $\mathrm{mg} / \mathrm{m}^{3}$ & 19.62 & 151.75 & 10.21 & 91.54 & 4.4 & 48.15 \\
\hline Sulfur Oxide (SOx) & $\mathrm{mg} / \mathrm{m}^{3}$ & 73.21 & 1002.2 & 32.44 & 492.61 & 12.35 & 217 \\
\hline HCL & $\mathrm{mg} / \mathrm{m}^{3}$ & 2.18 & 23.92 & 1.05 & 13.15 & 0.54 & 6.2 \\
\hline $\mathrm{HF}$ & $\mathrm{mg} / \mathrm{m}^{3}$ & 0.34 & 2.93 & 0.10 & 1.34 & 0.03 & 0.31 \\
\hline Voc & $\mathrm{mg} / \mathrm{m}^{3}$ & 14.14 & 156.84 & 5.16 & 78.57 & 2.25 & 58.9 \\
\hline $\begin{array}{l}\text { Carbon monoxide } \\
\text { (CO) }\end{array}$ & $\mathrm{mg} / \mathrm{m}^{3}$ & 13.82 & 603.26 & 22.47 & 404 & 2.77 & 70 \\
\hline $\begin{array}{l}\text { Carbon dioxide } \\
\qquad\left(\mathrm{CO}_{2}\right)\end{array}$ & $\%$ & $<0.2$ & 2.65 & 0.25 & 2.33 & 0.1 & 1.6 \\
\hline Oxygen $\left(\mathrm{O}_{2}\right)$ & $\%$ & 20.4 & 16.0 & 20.2 & 16 & 20.1 & 18 \\
\hline Temperature & ${ }^{\circ} \mathrm{C}$ & 36.40 & 82 & 37 & 85 & 37 & 82 \\
\hline
\end{tabular}


The study of atmospheric emissions (Table 5) shows that in the heavy-oil (FF1) production line, sulfur oxides $\left(\mathrm{SO}_{2}\right)$ has the highest rate $\left(1075 \mathrm{mg} / \mathrm{m}^{3}\right)$ followed by carbon monoxide $\left(617 \mathrm{mg} / \mathrm{m}^{3}\right)$. VOCs compounds and nitrogen oxide equivalents have similar value $\left(171 \mathrm{mg} / \mathrm{m}^{3}\right)$. The natural gas production line (FG1) has the same trend: the recorded values have been reduced and reach 525 $\mathrm{mg} / \mathrm{m}^{3}$ for sulfur oxide $\left(\mathrm{SO}_{2}\right)$ and a rate of $426 \mathrm{mg} / \mathrm{m}^{3}$ for carbon monoxide and $84 \mathrm{mg} / \mathrm{m}^{3}$ for VOC compounds and $102 \mathrm{mg} \mathrm{m}^{3}$ for nitrogen oxide equivalents. The cogeneration product line (SC2) highlights $230 \mathrm{mg} / \mathrm{m}^{3}$ of Sox, followed by $73 \mathrm{mg} / \mathrm{m}^{3}$ of carbon monoxide, $63 \mathrm{mg} / \mathrm{m}^{3}$ of VOC compounds and finally 53 $\mathrm{mg} / \mathrm{m}^{3}$ of Nitrogen oxides. Significantly reduce gaseous emissions, especially NOx levels below $20 \mathrm{ppm}$ can be achieved with hybrid/premix burners and below $10 \mathrm{ppm}$ with catalytic combustion (Table 1). In the longer term, achieve over 40 percent efficiency with less than $2 \mathrm{ppm} \mathrm{NO}$ in regenerative gas turbines with catalytic combustion [49]. An evaluation of $\mathrm{CO}_{2}$ emissions and the difference in using natural gas cogeneration system emissions are approximately $60 \%$ lower than the emissions of $\mathrm{CO}_{2}$ from Diesel Oil [50]. Compared to the different local standards or those of the Mediterranean countries [51] we can note that the production line in heavy fuel oil highlighted pollutants emissions relating to NOx well below Tunisian standards and are between the measured emissions in France $\left(200 \mathrm{mg} / \mathrm{m}^{3}\right)$ and in Italy $\left(100 \mathrm{mg} / \mathrm{m}^{3}\right)$. Pollutant emissions relating to SOx are lower than the Tunisian standard values but exceeded the limits set by the standard of the Mediterranean countries (France and Italy). The SOx pollutants shown in the tile's natural gas process emissions are lower than the standard limit value $\left(1000 \mathrm{mg} / \mathrm{m}^{3}\right)$. Pollutant emissions for CO and VOCs exceeded the Tunisian standard for both heavy oil and natural gas production lines, but did not exceed the emission standard in Italy and France $\left(1200 \mathrm{mg} / \mathrm{m}^{3}\right)$. The value of $\mathrm{HCl}$ and $\mathrm{HF}$ pollutant emissions for FF1 and FG1 production lines are below the emission values detected in France and Italy. This is due to the poverty of the clay material in Chloride and Fluoride [52]. For the cogeneration, process, all atmospheric emissions satisfied both Tunisian and Mediterranean standard requirements (Table 6).

\subsection{Effect of the Conversion Thermal Oil-Natural Gas-Cogeneration}

\subsubsection{Effect on Energy Consumption}

In terms of electricity consumption, the conversion-natural gas saved $5 \%$ of the energy requirement by modifying the type of fuel. This requirement decreased from 0.0121 Toe/ton of tile product for thermal oil installations at 0.0105 Toe/ton of product for natural gas installations. Whereas, cogeneration process can supply supplementary quantity of electrical energy and gives the opportunity to export electrical power to the external electric grid. The cogeneration process increase the energy saving at $16 \%$ of electric energy demand (Figure 6). The same result is reported by [34] in the Brazilian tile production equipped with an engine alternative, where $17 \%$ of electrical energy is exported to the external 
electric grid. The turbine options represent a reduction of $63 \%$ in an electric energy demand from the grid. The same study highlighted the total consumption of natural gas in São Paulo State considering three alternatives to attend the electric energy demand from industries. The electric power is generated in a thermo power plant fueled by heavy fuel oil (efficiency $21 \%$ ). The second situation considers an upgrade in the same power plant fueled by natural gas (efficiency $=35 \%)$. The third alternative considered is the electric demand supplied by a central thermal power located in São Paulo, natural gas fueled (efficiency = $55 \%)$.

In addition, thermal energy recorded a decrease of $52 \%$ by modifying the type of fuel: the conversion from thermal oil to natural gas showed a consumption of $0.0198 \mathrm{Toe} /$ Ton of product for natural gas line (FG1) instead of 0.0481 toe/ton of product for thermal oil line (FF1). The cogeneration line further reduces the specific consumption to reach 0.014 toe/ton of tile product (Figure 7). [53] estimate the mean consumption in the same sector and highlighted a similar reduction rate of $39 \%$ between thermal oil and natural gas lines and $70 \%$ compared to the cogeneration system.

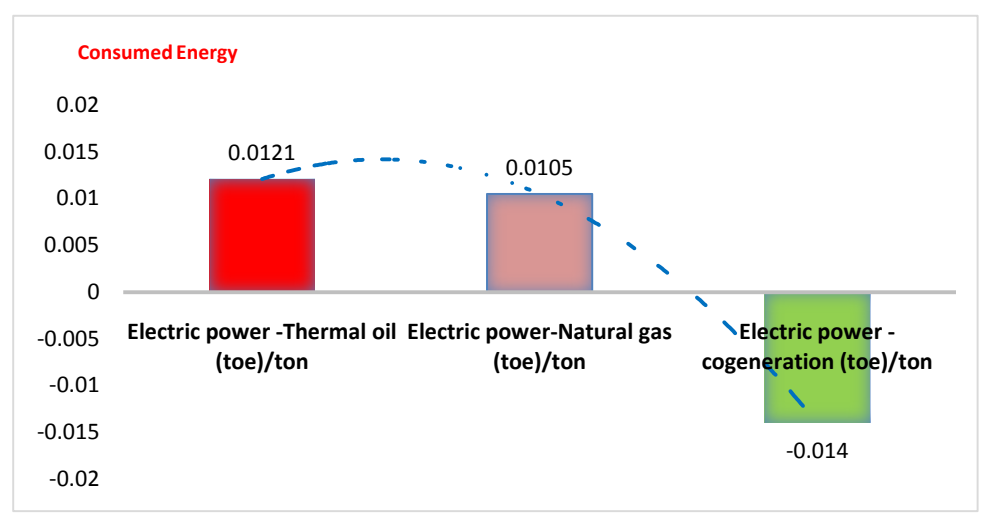

Figure 6. Effect of conversion Thermal oil-Natural gas-cogeneration on Electrical energy consumption.

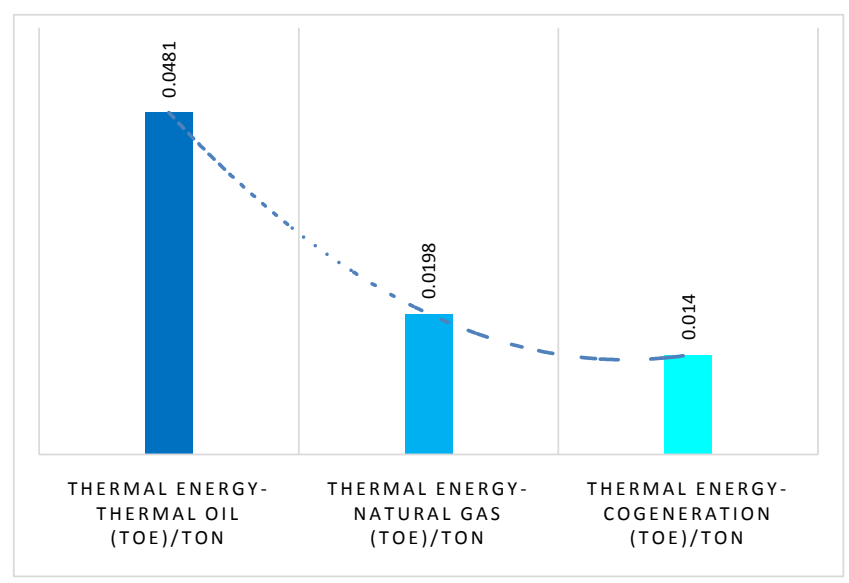

Figure 7. Effect of conversion Thermal oil-Natural gas-cogeneration on Thermal energy consumption. 
Table 6. Atmospheric emission values generated by different tile process.

\begin{tabular}{|c|c|c|c|c|c|c|c|}
\hline \multirow[t]{2}{*}{ Polluants } & & \multicolumn{3}{|c|}{$\begin{array}{l}\text { Cumulative level of } \\
\text { pollutants in the FF1, FG1 } \\
\text { and SC2 production lines }\end{array}$} & $\begin{array}{c}\text { Tunisian } \\
\text { standard } \\
\text { Thermal } \\
\text { oil }\end{array}$ & $\begin{array}{c}\text { Tunisian } \\
\text { standard } \\
\text { Naturel } \\
\text { Gas }\end{array}$ & $\begin{array}{l}\text { Cumulative } \\
\text { level of } \\
\text { pollutants } \\
\text { in the } \\
\text { Mediterranean } \\
\text { countries [39] }\end{array}$ \\
\hline & & \multicolumn{5}{|c|}{ Dryer and Dryer and Dryer and Dryer and Dryer and } & $\begin{array}{c}\text { Dryer } \\
\text { and Kiln }\end{array}$ \\
\hline $\begin{array}{l}\text { Nitricoxide } \\
\text { (NO) }\end{array}$ & & 15.48 & 36.92 & 24 & - & - & - \\
\hline $\begin{array}{c}\text { Nitrogen } \\
\text { oxide (NOx) }\end{array}$ & $\mathrm{mg} / \mathrm{m}^{3}$ & 134.5 & 64.78 & 30 & - & - & - \\
\hline $\begin{array}{l}\text { Total Nitrogen } \\
\text { Oxide or } \\
\text { equivalent }\end{array}$ & $\mathrm{mg} / \mathrm{m}^{3}$ & 171.37 & 101.75 & 52.55 & 450 & 180 & $100-200$ \\
\hline $\begin{array}{l}\text { Sulfur Oxide } \\
\text { (SOx) }\end{array}$ & $\mathrm{mg} / \mathrm{m}^{3}$ & 1075.41 & 525.05 & 229.35 & 1700 & 35 & $<1000$ \\
\hline HCL & $\mathrm{mg} / \mathrm{m}^{3}$ & 26.1 & 14.2 & 6.74 & - & - & $<270$ \\
\hline HF & $\mathrm{mg} / \mathrm{m}^{3}$ & 3.27 & 1.44 & 0.34 & - & - & $<350$ \\
\hline VOC & $\mathrm{mg} / \mathrm{m}^{3}$ & 170.98 & 83.73 & 61.15 & - & - & $<250$ \\
\hline $\begin{array}{l}\text { Carbon } \\
\text { monoxide } \\
(\mathrm{CO})\end{array}$ & $\mathrm{mg} / \mathrm{m}^{3}$ & 617.08 & 426.47 & 72.77 & 100 & 100 & $500-1200$ \\
\hline $\begin{array}{l}\text { Carbon dioxide } \\
\qquad\left(\mathrm{CO}_{2}\right)\end{array}$ & $\%$ & 2.67 & 2.58 & 1.7 & & & - \\
\hline
\end{tabular}

\subsubsection{Effect on Atmospheric Pollutants}

The conversion from thermal oil to natural gas highlights a reduction rate of the main pollutants at drier process of $80 \%$ for nitrogen oxides (NOx), $56 \%$ for sulfur oxides (SOx), $56 \%$ for fluorinated compounds, $52 \%$ for chlorinated compounds and $64 \%$ for volatile organic compounds. Whereas, in case of the use of cogeneration system. This rate reaches $89 \%$ for nitrogen oxides, $62 \%$ for sulfur oxides and $77 \%$ for volatile organic compounds (Figure 8(a)). In firing process the conversion thermal oil-natural gas highlights a reduction of $36 \%$ of nitrogen oxides, $51 \%$ of sulfur oxides, $50 \%$ of $\mathrm{COVx}, 55 \%$ of fluorinated compounds, $36 \%$ of chlorinated compounds and $34 \%$ of $\mathrm{CO}_{2}$. While, the conversion thermal oil-cogeneration system records a reduction of $67 \%$ for nitrogen oxides, $80 \%$ for sulfur oxides, $58 \%$ for chlorinated compounds, $89 \%$ for compounds fluorinated, $64 \%$ for volatile organic compounds and $48 \%$ for $\mathrm{CO}_{2}$ (Figure 8 (b)). [54] reported that in an evaluation of $\mathrm{CO}_{2}$ emissions in using a natural gas cogeneration system emissions is approximately $60 \%$ lower than the emissions of $\mathrm{CO}_{2}$ from diesel oil. [55] highlighted that the use of nearly $110,600 \mathrm{Sm}^{3}$ per year of natural gas can be retained while the production of almost 164 tons of $\mathrm{CO}_{2}$ can be reduced per year. The heat recovery duty in heat pipe heat exchangers can reach $40 \%$ of the total energy. 

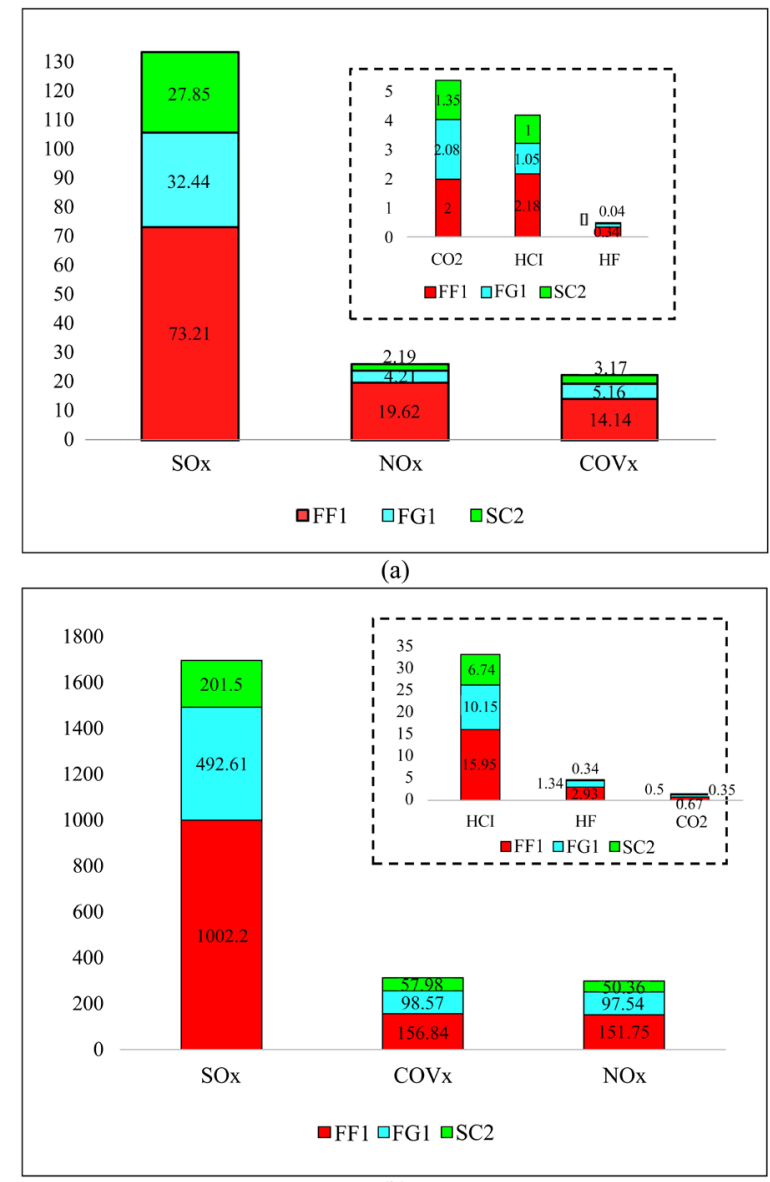

(b)

Figure 8. Effect of energy process conversion on atmospheric emission ((a) Drier process; (b) Kiln process).

Operational data measured externally (non-continuous) revealed a total gas atmospheric emission factor for the thermal oil line (FF1) production line equal to $2.066 \mathrm{~g}$ (pollutants) $/ \mathrm{kg}$ of tile product manufactured against a total atmospheric emission factor of natural gas line (FG1) equal to $1.16 \mathrm{~g}$ (pollutants) $/ \mathrm{kg}$ of tile product manufactured. The cogeneration system line (SC2) records a total atmospheric emission factor $0.43 \mathrm{~g}$ (pollutants) $/ \mathrm{kg}$ of tile product manufactured (Figure 9). This emission factor is comparable to that detected in European countries. In fact, Portugal gives the lowest emission factor of $1.11 \mathrm{~g} / \mathrm{kg}$ of red product followed by France records an average emission factor of $2.37 \mathrm{~g} / \mathrm{kg}$ of red product. Italy records an emission factor of $3.48 \mathrm{~g} / \mathrm{Kg}$ of red product. Germany records the emission factor of $4.13 \mathrm{~g} / \mathrm{kg}$ red product, while Belgium has the highest emission factor of $4.9 \mathrm{~g} / \mathrm{kg}$ tile product [51]. This energy conversion revealed a remarkable rise in carbon monoxide and carbon dioxide levels at the kiln probably due to an incomplete combustion process. In addition, the firing process conversion provides better firing efficiency and the elimination of soot and ash emissions [56]. Gas burners lend themselves to advanced automatic control systems, saving energy, reducing specific fuel consumption and avoiding costly dusting process [57] [58]. 


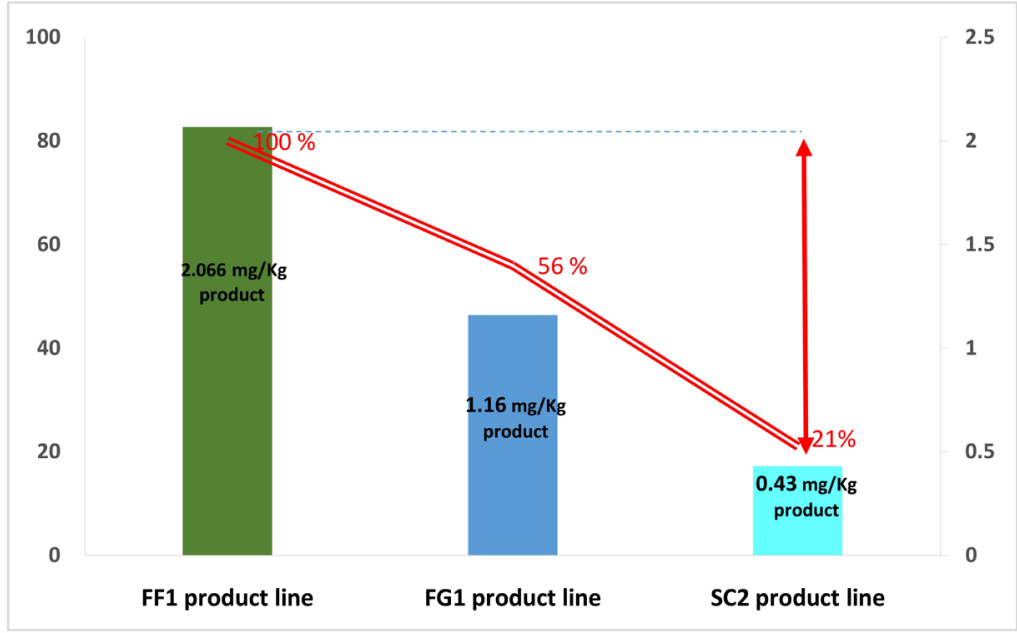

Figure 9. Specific atmospheric gas emission factor.

\section{Conclusion}

The tile ceramic sector, in Tunisia, produces over 10 million tons/year of tiles, based on $100 \%$ clay ceramic body. Clay is dried by using natural process under the sun, but it is bringing some environmental problems, due to gas emissions to the atmosphere and fuel costs. This study evaluated the effect of energy conversion from traditional energy (thermal oil) to an innovative process (cogeneration) to reduce the energy consumption and the atmospheric gas emissions. Admittedly, the conversion of heavy fuel oil to natural gas and cogeneration technology will guarantee the reduction in thermal and electrical consumption as well as an improvement in the various consumption ratios and supply a significant reduction in the atmospheric emission factor of the main pollutants. However, this energy conversion will have to be consolidated by the introduction of other technologies in order to transform the tile industry into an energy-efficient industry that respects the environment. The current method of diagnosing energy consumption in the tile products manufacturing industry in Tunisia is still traditional. It would be wise to more accurately calculate the performance of the manufacturing process. Indeed, the classic energy audits are a simple energetic quantification, which must be consolidated by the analysis of exergy (eco-efficiency). As a result, with regard to the overall energy consumption, the generation of electric energy from a natural gas from tile local cogeneration unit should have more advantages for both economic and environmental purpose.

\section{Conflicts of Interest}

The authors declare no conflicts of interest regarding the publication of this paper.

\section{References}

[1] Baccour, Z., et al. (2011) Caractérisation physico chimique et Mécanique de 
Matériaux Céramiques obtenus à partir des argiles tunisiennes. Verres, Céramiques et Composites, 1, 25-33.

[2] Pardo, F., Meseguer, S., Jordán, M.M., Sanfeliu, T. and González, I. (2011) Firing Transformations of Chilean Clays for the Manufacture of Ceramic Tile Bodies. Applied Clay Science, 51, 147-150. https://doi.org/10.1016/j.clay.2010.11.022

[3] Ben M’barek Jemaï, M., Sdiri, A., Errais, E., Duplay, J., Ben Saleh, I., Zagrarni, M.F. and Bouaziz, S. (2015) Characterization of the Ain Khemouda Halloysite (Western Tunisia) for Ceramic Industry. Journal of African Earth Sciences, 111, 194-201. https://doi.org/10.1016/j.jafrearsci.2015.07.014

[4] Ben Salah, I., Ben M'barek-Jemaï, M., Sdiri, A. and Boughdiri, M. (2018) Potential Use of Lower Cretaceous Clay (Kef Area, Northwestern Tunisia) as Raw Material to Supply Ceramic Industry. Applied Clay of Sciences, 161, 151-162. https://doi.org/10.1016/j.clay.2018.04.015

[5] Eloussaief, M., Fakhfakh, N., Sdiri, A., Bouaziz, S. and Benzina, M. (2012) An Experimental Design for the Optimization of Brick Manufacturing Procedure: Application on the Late Miocene Clays, Southern Tunisia. Transactions of the Indian Ceramic Society, 71, 195-202. https://doi.org/10.1080/0371750X.2012.762154

[6] Bovea, M.D., et al. (2010) Environmental Performance of Ceramic Tiles: Improvement Proposals. Materials \& Design, 31, 35-41.

https://doi.org/10.1016/j.matdes.2009.07.021

[7] Hachani, M., Hajjaji, W., Moussi, B., Medhioub, M., Rocha, F., Labrincha, J.A. and Jamoussi, F. (2012) Production of Ceramic Bodies from Tunisian Cretaceous Clays. Clay Minerals, 47, 59-68. https://doi.org/10.1180/claymin.2012.047.1.59

[8] Ben M'Barek-Jemaï, M., Sdiri, A., Ben Salah, I., et al. (2017) Geological and Technological Characterization of the Late Jurassic-Early Cretaceous Clay Deposits (Jebel Ammar, Northeastern Tunisia) for Ceramic Industry. Journal of African Earth Sciences, 129, 282-290. https://doi.org/10.1016/j.jafrearsci.2017.01.019

[9] Jeridi, K., Hachani, M., Hajjaji, W., Moussi, B., Medhioub, M., López-Galindo, A., Kooli, F. and Zargouni (2008) Ceramic Behaviour of Tunisian Clays during Earthenware Tile Production by Dry and Wet Grinding Processes. Clay Minerals, 43, 339. https://doi.org/10.1180/claymin.2008.043.3.01

[10] Jamoussi, F., Bédir, M., Boukadi, N., Kharbachi, S., Zargouni, F., López-Galindo, A. and Paquet, H. (2003) Répartition des minéraux argileux et contrôle tectono-eustatique dans les bassins de la marge tunisienne. Comptes Rendus Geoscience, 335, 175-183. https://doi.org/10.1016/S1631-0713(03)00014-2

[11] Medhioub, M., Hajjaji, W., Hachani, M., Lopez-Galindo, A., Rocha, F., Labrincha, J.A. and Jamoussi, F. (2012) Ceramic Tiles Based on Central Tunisian Clays (Sidi Khalif Formation). Clay Minerals, 47, 165-175.

https://doi.org/10.1180/claymin.2012.047.2.02

[12] Ben M’barek-Jemaï, M., Sdiri, A., Ben Salah, I., Ben Aissa, L., Bouaziz, S. and Duplay, J. (2017) Geological and Technological Characterization of the Late Jurassic-Early Cretaceous Clay Deposits (Jebel Ammar, Northeastern Tunisia) for Ceramic Industry. Journal of African Earth Sciences, 129, 282-290.

https://doi.org/10.1016/j.jafrearsci.2017.01.019

[13] Labrincha, F.J. and Jamoussi, F. (2008) Technological Behaviour of Some Tunisian Clays Prepared by Dry Ceramic Processing. Clay Minerals, 43, 339-350. https://doi.org/10.1180/claymin.2008.043.3.01

[14] Mahmoudi, S., Srasra, E. and Zargouni, F. (2008) Characterization of Valangenian-Hauterivian Clays of Northwestern Tunisia for Ceramic. Arabian Journal for 
Science and Engineering, 33, 229-243.

[15] Balli, L., et al. (2014) Modélisation et simulation numérique des transferts thermiques dans un four à poterie, Verres. Céramiques \& Composite, 3, 12-17.

[16] Michot, A. (2008) Caractéristiques thermo physique de matériaux à base d'argile: Evolution avec traitements thermiques jusqu'à $1400{ }^{\circ} \mathrm{C}$. Thèse doctorat, Université de Limoges Faculté des Sciences, 5.

[17] Jordán, M.M., Montero, M.A., Meseguer, S. and Sanfeliu, T. (2008) Influence of Firing Temperature and Mineralogical Composition on Bending Strength and Porosity of Ceramic Tile Bodies. Applied Clay Science, 42, 266-271. https://doi.org/10.1016/j.clay.2008.01.005

[18] El Hajer, H. (1983) Contrôle et conduite numérique d'un four tunnel d'industrie céramique. Thèse de doctorat, Université Paul Sabatier, Toulouse, 10.

[19] Kassinopoulos, M. (1980) Modélisation et commande sous optimale d'un four d'industrie céramique. Thèse de doctorat, Université Paul Sabatier des Sciences, Toulouse, 4 .

[20] Carvalho, M. and Silva, J. (2017) Second Law Assessment of a Hoffmann Kiln for the Red Ceramics Industry. Journal of the Brazilian Society of Mechanical Sciences and Engineering, 40, Article No. 525. https://doi.org/10.1007/s40430-018-1444-6

[21] Lazrabal, A.E. (1985) Identification et optimisation d'un four tunnel d'industrie céramique. Thèse de doctorat, Université Paul Sabatier, Toulouse, 10.

[22] Standard NF M03-018 (2010) Solid Mineral Fuels-Determination of Nitrogen.

[23] Standard NF M03-032 (2015) Charbon et coke-Dosage du carbone et de l'hydrogène par combustion à haute temperature.

[24] Standard NF T 60-154. Teneur en eau-Étanche et inerte Karl Fischer.

[25] Wauquier, J.P. (1994) Le raffinage de petrole. Produits petroliers-Schémas de fabrication-Institut français de pétrole-Edition Technip.

[26] Standard ISO 14532 (2014) Terms, Definitions, Symbols, and Abbreviations Used in the Field of Natural Gas.

[27] Standard NF EN 14211(2005) Qualité de l'air ambiant-Méthode normalisée pour le mesurage de la concentration en dioxyde d'azote et monoxyde d'azote par chimiluminescence.

[28] Standard NF EN 14626 (2005) Qualité de l'air ambiant-Méthode normalisée de mesurage de la concentration en monoxyde de carbone par la méthode à rayonnement infrarouge non dispersive.

[29] Standard NF EN 14212 (2005) Qualité de l'air ambiant-Méthode normalisée pour le mesurage de la concentration en dioxyde de soufre par fluorescence UV.

[30] Mukherjee, S. and Ghosh, B. (2013) The Science of Clays: Applications in Industry, Engineering and Environment. In: The Science of Clays: Applications in Industry, Engineering and Environment, Springer, Berlin, 46-47.

[31] American Society of Testing Materials (ASTM) (2018) Standard Test Methods for Sampling and Testing. Brick and Structural Clay Tile C67 1-17 (USA: American Society of Testing Materials).

[32] Uche, J., Valero, A. and Serra, L. (2006) Fundamentals of Exergy Cost Accounting and Thermoeconomics. Part I: Theory. Journal of Energy Resources Technology, 128, 1-8. https://doi.org/10.1115/1.2134732

[33] Monfort, E., Mezquita, A., Vaquer, E., Mallol, G., Alves, H.J. and Boschi, A.O. (2012) Consumo de energía térmica y emisiones de dióxido de carbono en la fabri- 
cación de baldosas cerámicas Análisis de las industrias Española y Brasileña. Boletín de la Sociedad Española de Cerámica y Vidrio, 51, 275-284.

https://doi.org/10.3989/cyv.392012

[34] Messias Laiete, S., LaraDos Santos, M., Helena, P. and Mariano Dos Santos, M. (2012) Fuels: Analysis of Plant Performance and Environmental Impact. In: de Souza, G., Ed., Thermal Power Plant Performance Analysis, Springer, London, 61-90. https://doi.org/10.1007/978-1-4471-2309-5_4

[35] Goldoni, S. and Bonoli, A. (2006) A Case Study about LCA of Ceramic Sector: Application of Life Cycle Analysis Results to the Environment Management System Adopted by the Enterprise. University of Bologna, Bologna.

[36] Bustos, A.Y. and Guevara, E. (2007) Evaluación comparativa técnica, económica y ambiental de hornos colmena Utilizando como combustible carbón, fuel oíl, gas natural y el nuevo combustible CCTA (Colombia: Universidad Francisco de Paula Santander).

[37] Samah, O.D., et al. (2006) Echanges thermiques dans un four à combustible eau sous pression et pétrole lampant: Modélisation d'un cycle de caisson. Journal des Sciences pour l ingénieur, 6, 11-17. https://doi.org/10.4314/jspi.v6i1.30024

[38] Bovea, M.D., et al. (2010) Environmental Assessment of Alternative Municipal Solid Waste Management Strategies. A Spanish Case Study. Waste Management, 30, 2383-2395. https://doi.org/10.1016/j.wasman.2010.03.001

[39] Unidad de Planeacion Minero Energetica (UPME) (2008) Sistema de Gestión Integral de la Energía. Guía para la implementación (Colombia: Unidad de Planeación Minero-Energética).

[40] Monroy, R., Romero, Y.A. and Gelves, J.F. (2018) Consumption of Energy in the Manufacturing of Ceramic Brick in the Metropolitan Area of Cúcuta, Colombia. Journal of Physics. Conference Series, 1126, Article ID: 012014. https://doi.org/10.1088/1742-6596/1126/1/012014

[41] Gerarden, T.D., Newell, R.G. and Stavins, R.N. (2015) Assessing the Energy-Efficiency Gap. National Bureau of Economic Research, Working Paper Series No. 20904. https://doi.org/10.3386/w20904

[42] Chan, Y. and Kantamaneni, R. (2015) Study on Energy Efficiency and Energy Saving Potential in Industry from Possible Policy Mechanisms. ICF International, Fairfax.

[43] Jouhara, H., Khordehgah, N., Almahmoud, S., Delpech, B., Chauhan, A. and Tassou, S.A. (2018) Waste Heat Recovery Technologies and Applications. Thermal Science and Engineering Progress, 6, 268-289. https://doi.org/10.1016/j.tsep.2018.04.017

[44] Mezquita, A., Monfort, E., Vaquer, E., Ferrer, S., Arnal, M.A., Toledo, J. and Cuesta, M.A. (2012) Energy Optimisation in Ceramic Tile Manufacture by Using Thermal Oil. Conference Paper. Qualicert February.

[45] García Afnador, N., Gómez Guerrero, G. and Monroy Sepúlveda, R. (2012) Mechanical \& Physical Properties of Solid, Masonry Ceramic Bricks. Ciencia e Ingeniería Neogranadina, 22, 43-58. https://doi.org/10.18359/rcin.248

[46] Alves, H.J., Melchiades, F.G. and Boschi, A.O. (2008) Consumption of Natural Gas in Brazilian Ceramic Tile Industry. Cerâmica, 54, 326-331. https://doi.org/10.1590/S0366-69132008000300009

[47] Almeida, M.I., et al. (2010) Life Cycle Assessment (Cradle to Gate) of a Portuguese Brick in Portugal SB10-Sustainable Building Affordable to All. Universidade do Minho, Vilamoura. 
[48] Koroneos, C. and Dompros, A. (2007) Environmental Assessment of Brick Production in Greece. Building and Environment, 42, 2114-2123. https://doi.org/10.1016/j.buildenv.2006.03.006

[49] Anson, D. and Sheppard, W.J. (1992) Impact of Ceramic Components in Gas Turbines for Industrial Cogeneration. The American Society of Mechanical Engineers, New York. https://doi.org/10.1115/92-GT-393

[50] Natália, A., Brasil, W. and Hirdan, K. (2019) Cogeneration Potential in the Industrial Sector and Gas Emission Reduction: A Case Study. Journal of Atmospheric Science Research, 2, 10-17.

[51] European Bank (2012) Sub-Sectoral Environmental Guidelines-Brick Manufacture.

https://www.ebrd.com/documents/environment/subsectoral-brick-manufacturing.p df

[52] Tikul, N. and Srichandr, P. (2010) Assessing the Environmental Impact of Ceramic Tile Production in Thailand. Journal of the Ceramic Society of Japan, 118, 887-894. https://doi.org/10.2109/jcersj2.118.887

[53] Woolley, E., Luob, Y. and Simeone, A. (2018) Industrial Waste Heat Recovery: A Systematic Approach. Sustainable Energy Technologies and Assessments, 29, 50-59. https://doi.org/10.1016/j.seta.2018.07.001

[54] Monfort, E., Mezquita, A., Granel, R., Vaquer, E., Escrig, A., Miralles, A. and Zaera, V. (2010) Análisis de consumos energéticos y emisiones de dióxido de carbono en la fabricación de baldosas cerámicas. BOL SOC ESP CERAM V, 49, 303-310.

[55] Egilegora, B., Jouharab, H., Zuazuac, J., Al-Mansourd, F., Plesnike, K., Montorsif, L. and Manzinig, L. (2019) ETEKINA: Analysis of the Potential for Waste Heat Recovery in Three Sectors: Aluminium Low Pressure Die Casting, Steel Sector and Ceramic Tiles Manufacturing Sector. International Journal of Thermofluids, 1-2, Article ID: 100002. https://doi.org/10.1016/j.ijft.2019.100002

[56] Escardinio, A. (2005) El esfuerzo en innovación de la industria cerámica de la Comunidad Valenciana para reducir las emisiones de dióxido de carbono. In: Simposio internacional sobre el cambio climático, desde la ciencia a la sociedad, Generalitat Valentina, Valencia, 121-133.

[57] Schulze, M., et al. (2016) Energy Management in Industry. A Systematic Review of Previous Findings and an Integrative Conceptual Framework. Journal of Cleaner Production, 112, 3692-3708. https://doi.org/10.1016/j.jclepro.2015.06.060

[58] Gondim, P.A., et al. (2006) Viabilidade técnica de conversão de cerâmicas do Rio Grande do Norte para Gás Natural. Cerâmica Industrial, 13, 42-46. 


\section{Abbreviation}

LHV: Low Heat Value

HHV: High Heat Value

toe: Total oil equivalent

LPG: Liquefied petroleum gas

$E \tau=$ Thermal energy $(k W h)$

mc. Coal mass $(\mathrm{kg})$

cp: Calorific value $(\mathrm{Kwh} / \mathrm{kg})$

$\varepsilon$. Vacuum rate in the tunnel kiln (\%)

$S_{h}$ : Horizontal section of the tunnel kiln $\left(\mathrm{m}^{2}\right)$

$\rho_{s}$ : Density of the load $\left(\mathrm{Kg} / \mathrm{m}^{3}\right)$

$\rho_{g}$ : Density of the gas $\left(\mathrm{Kg} / \mathrm{m}^{3}\right)$

$C_{p s}:$ Heat capacity at constant pressure of the load $\left(J / \mathrm{Kg}^{\circ} \mathrm{K}\right)$

$C_{p g}:$ Heat capacity at constant gas pressure $\left(J / \mathrm{Kg}^{\circ} \mathrm{K}\right)$

$D_{m g}:$ Mass flow rate of gas $(\mathrm{Kg} / \mathrm{s})$

$A_{G s}$ Coefficient associated with convective heat transfer between load and gas $\left(J / s . m .{ }^{\circ} \mathrm{K}\right)$

$B_{p s}:$ Coefficient associated with radiation heat transfer between the load and wall $\left(J / s . m .{ }^{\circ} K^{4}\right)$

$A_{G T a}:$ Coefficient associated with convective heat transfer between the gas and the external environment $\left(J / s . m .{ }^{\circ} \mathrm{K}\right)$ 